\title{
The Binding Force of Nascent Norms of International Law
}

\author{
Anthony R. Reeves \\ Department of Philosophy \\ Binghamton University (SUNY)
}

Originally published in The Canadian Journal of Law and Jurisprudence, Vol. 28, No.1 (January 2014), 145-166.

Link: https://www.law.uwo.ca/research/the_canadian_journal_of_law_and_jurisprudence/2014_january.html

Demonstrating that a developing norm is not yet well established in international law is frequently thought to show that states (and other agents) are not bound by the norm as law. More precisely, showing that a purported international legal norm has only limited support from well-established international legal sources is seen as sufficient for blocking an attribution of an obligation on the part of states to comply with the norm in virtue of its legal status. The appeal to the nascent character of a developing legal norm is treated as a defense against a claim that one is bound to carry out the demands of the norm because it is law. Consider the following hypothetical dialogue:

International Legal Community (ILC): “State A, you must not x, for norm $\mathrm{N}$ of international law forbids x.”

State A: "On the contrary, $\mathrm{N}$ is not well-established. Sure, it has received the endorsement of the UN General Assembly, and some states have accorded their behavior with $\mathrm{N}$ and seen $\mathrm{N}$ as binding as law. However, we have not done this, and the practice of regarding $\mathrm{N}$ as law is far from universal.”

ILC: "But x-ing is unethical, you ought not do it."

$\underline{\text { State A: }}$ "Frankly, we disagree in the details, we think a more nuanced norm forbidding xactions of a certain type is morally more precise. Our current proposed course of action does not fall within that sub-type. In any case, this is beside the point. Your claim was that it was imperative that we not-x in light of norm N's status as law. As we have shown, $\mathrm{N}$ is (at best) nascent and crystallizing. Therefore, we are not bound by $\mathrm{N}$, we do not have the type of obligations to not-x as we would have if you had a better legal case."

The paper benefited greatly from the comments of Larry May, Max Pensky, Nicole Hassoun, Kristen Hessler, Jens Ohlin, Christopher Morgan-Knapp, Melissa Zinkin, Benjamin Yost, audience members at the Binghamton University PPL International Law Conference, and an anonymous reviewer for Canadian Journal of Jurisprudence. 
A's position is that N's nascent legal status, in itself, has implications for the role it ought to play in practical reason. I will summarize this view with the less-precise formulation that nascent international law is non-binding. From the standpoint of responsible practical reason, this view is basically mistaken. A's rebuttal of the ILC is not successful. A has not shown that it does not have obligations of the very same character it would have if $\mathrm{N}$ were better established international legal doctrine. I will argue that nascent legal norms are frequently binding for subjects of international law, and much in the same way other international legal norms are binding on responsible practical reason. To put it otherwise, the role nascent international legal norms ought to play in the practical reasoning of international agents is not qualitatively different than that of better-established doctrine. Moreover, considering the sense in which nascent legal norms are binding illuminates, I contend, some general features of the moral authority of international law.

The argument here is fundamentally moral in character, though it depends upon several assumptions regarding the nature of international law, and law generally. Most of these assumptions are uncontroversial, but some may be more contentious. My strategy will be to describe the relevant features of international law as much as is necessary for the moral argument, provide the moral argument, and then defend the descriptive claims (in greater detail) and respond to some remaining normative concerns. I hope that this temporary sidelining of some details will help keep in relief those phenomena of international law centrally important for the moral argument.

\section{The Authority of Nascent International Law}

\section{A. The Problem}

Significant attention has been given to standard jurisprudential issues in the domain of international law. Questions concerning the nature of international legal norms, whether international law has a rule of recognition, how international law otherwise compares to state law, and the factual role of various institutions in international legal practice have received consideration.' Outside specifically

\footnotetext{
${ }^{1}$ See HLA Hart, The Concept of Law, 2nd ed by Penelope A Bulloch \& Joseph Raz (New York: Oxford University Press, 1994) at 213-237; Anthony D’Amato, “The Neo-Positivist Concept of International Law" (1965) 59 AJIL 321; GJH van Hoof, Rethinking the Sources of International Law (Deventer: Kluwer, 1983); Thomas Franck, The Power of Legitimacy Among Nations (New York: Oxford University Press, 1990); Alan Boyle \& Christine Chinkin, The Making of International Law (New York: Oxford University Press, 2007); David Lefkowitz, “(Dis)Solving the Chronological Paradox in Customary International Law: A Hartian Approach" (2008) 21 Can JL \& Jur 129; Samantha Besson, "Theorizing the Sources of International Law" in Samantha Besson \& John Tasioulas, eds, The Philosophy of
} 
philosophical forums, a sizeable literature (some of which will be mentioned shortly) has developed regarding doctrinal issues, both for established and developing doctrine. Moreover, an extensive philosophical literature now exists on many pressing matters of international morality relevant to the substance of international law, for example, on war, intervention, international crime, human rights, and sovereignty. ${ }^{2}$ The following, however, has received comparatively little philosophical attention: what moral reason do subjects of international law have to comply with its norms in virtue of their legality? Why (aside from prudence), and in what way, should subjects take seriously international legal norms in their reasoning about how to act? My concern is with this question.

The issue has not been wholly neglected, ${ }^{3}$ and traditionally (for state law) it falls under the rubric of political obligation. However, I am not aware of any fully developed attempt to extend a theory of political obligation to the international sphere, though David Lefkowitz has recently

International Law (New York: Oxford University Press, 2011) at 163-85; David Lefkowitz, "The Sources of International Law: Some Philosophical Reflections" in Samantha Besson \& John Tasioulas, eds, The Philosophy of International Law (New York: Oxford University Press, 2011) at 187-203.

${ }^{2}$ Any list here will be a very selective gesture, but prominent contributions include Michael Walzer, Just and Unjust Wars (New York: Basic Books, 1977); Charles Beitz, Political Theory and International Relations (Princeton: Princeton University Press, 1979); John Rawls, The Law of Peoples (Cambridge: Harvard University Press, 1999); Larry May, Crimes Against Humanity: A Normative Account (New York: Cambridge University Press, 2005); Jeff McMahan, "The Morality of War and the Law of War" in David Rodin \& Henry Shue, eds, Just and Unjust Warriors (Oxford: Clarendon Press, 2008) at 19-43; James Griffin, On Human Rights (New York: Oxford University Press, 2008); Andrew Altman \& Christopher Heath Wellman, A Liberal Theory of International Justice (New York: Oxford University Press, 2009); Charles R Beitz, The Idea of Human Rights (New York: Oxford University Press, 2009); Allen Buchanan, Human Rights, Legitimacy, \& the Use of Force (New York: Oxford University Press, 2010).

${ }^{3}$ For a view skeptical that international law is a source of non-prudential reasons, see Jack L Goldsmith \& Eric A Posner, The Limits of International Law (New York: Oxford University Press, 2005) at 185-224. For a reply, see Allen Buchanan, "Democracy and the Commitment to International Law" (2006) 34 Ga J Int'l \& Comp L 305. For additional treatment of the issue, see Samantha Besson, "The Authority of International Law - Lifting the State Veil” (2009) 31 Sydney L Rev 343; John Tasioulas, "The Legitimacy of International Law" in Samantha Besson \& John Tasioulas, eds, The Philosophy of International Law (New York: Oxford University Press, 2011) at 97-116; Lefkowitz, "The Sources of International Law: Some Philosophical Reflections," supra note 1. Tasioulas, Besson, and Lefkowitz draw largely on Raz's theory of authority in their accounts. My approach is not inconsistent with that particular understanding of instrumental political authority, but it does not presuppose the mechanics or details of Raz's theory. For his recent discussion of the theory, see Joseph Raz, "The Problem of Authority: Revisiting the Service Conception” (2006) 90 Minn L Rev 1003. 
illustrated the promise of a fairness-based approach. ${ }^{4}$ Moreover, traditional approaches to political obligation (founded in the moral terrain of consent, fairness, gratitude, common association, justice, and democratic procedure) appear unpromising in the realm of international law given its structural, procedural, and moral shortcomings. ${ }^{5}$ To put it bluntly, international law is largely unjust, unfair, undemocratic, uncharitable, and not associative in a way that could ground compliance obligations. It is frequently thought that consent, given the prevalence of treaties in international law, is the major source of its authority. However, there are severe obstacles for this thought (even for treaties), ${ }^{6}$ and it would have little applicability to customary law. Why, then, should the responsible subject be concerned with such law? Moreover, what attitude should subjects have towards nascent legal norms?

Strictly speaking, the account I give here is not predicated on the failure of extant accounts of political obligation for the international domain. ${ }^{7}$ Yet, given the importance of the international legal order, the lack of promise of traditional approaches should motivate us to look elsewhere to substantiate international law's authority (so far as it deserves it). I aim to provide sufficient conditions for the authority of international legality in spite of systemic injustice, unfairness, and the like, and to demonstrate that a surprising conclusion follows for nascent doctrine. Namely, that subjects can have demanding obligations to comply with such norms precisely in virtue of their legal character. Given the current state of international law, as a developing legal order with decentralized modes of doctrinal development and interpretation, this is a practically significant result for the question of responsible state behavior under law. Before providing the argument, though, we need a more definite understanding of the idea of "nascent law" and the special problems it poses in the international context.

\footnotetext{
${ }^{4}$ David Lefkowitz, “The Principle of Fairness and States' Duty to Obey International Law" (2011) 24 Can JL \& Jur 347. Even on Lefkowitz's account, however, the obligation would be restricted to human rights respecting, democratic states whose officials have knowingly accepted the benefits of the international legal order.

${ }^{5}$ See Anthony R Reeves, "The Moral Authority of International Law" (2010) 10 APA Newsletter on Phil $\&$ Law 13. Of course, the notion that subjects of even decently just and democratic states have a general obligation to obey the law remains controversial. See A John Simmons, Justification and Legitimacy: Essays on Rights and Obligations (New York: Cambridge University Press, 2001). ${ }^{6}$ Allen Buchanan, "The Legitimacy of International Law" in Samantha Besson \& John Tasioulas, eds, The Philosophy of International Law (New York: Oxford University Press, 2010) 79 at 90-94.

${ }^{7}$ So one need not fully agree with my blunt assessment above to accept the argument of the paper. Here I speak to the proper motivations for developing legal theory in a certain direction.
} 


\section{B. Nascent International Law}

One source of international law is custom, and customary international law is created and developed by actual state practice. ${ }^{8}$ The power to develop customary international legal doctrine is not, many observers have noted, equal. States with greater presence and influence in international relations have greater ability to determine the shape of customary international law. The interpretation of other sources of international law (e.g., treaties, formal agreements, and enactments/statements of recognized organizations) also frequently appeals to state practice. For instance, the history of how state parties have regarded the explicit terms of a treaty is seen as a basis for understanding the content of the treaty -- that is, which norms the treaty factually contains. It is commonly understood that for both matters of establishing the existence of customary law and identifying a norm interpretively, two elements must be present. First, there must be-widespread and regular state behavior that accords with the norm. Second, there must be a recognition by relevant state institutions that such behavior is legally obligatory, an opinio juris. ${ }^{9}$

In one respect, then, much international law looks quite different from the municipal law of states. The distinction between legislation and compliance is far less pronounced, such that it is more difficult to differentiate law-making from obedience as a subject of law. The manner in which a state, or other agency, complies with international law may determine the content of international law. Jeremy Waldron highlights the horizontal character of such law:

[I]t must be understood that the state is not just a subject of international law; it is additionally both a source and an official of international law. International law regulates a

\footnotetext{
${ }^{8}$ Other agencies can be both subjects and, in virtue of their practice, creators of international law. Having acknowledged this, I will, for the sake of avoiding awkward locutions, simply refer to states. The argument applies with equal force to non-state subjects of international law.

${ }^{9}$ For a general discussion of these matters for traditional customary law, see Anthonio Cassese, International Law (New York, Oxford University Press, 2005) at 153-69. Regarding treaty interpretation, see Richard Gardiner, Treaty Interpretation (New York: Oxford University Press, 2010) at 203-49. How exactly state practice and the opinio juris ought to be ascertained, and what role, precisely, they ought to and do play as sources of law (e.g., how far state practice must be shown before appealing to the opinio juris of states) are matters of significant controversy. This controversy is not idle, but I think we can sidestep some of the issues, at least for the issue of responsible reasoning under international law, on the approach advocated here. For a discussion of the central issues, see Prosper Weil, "Towards Relative Normativity in International Law?" (1983) 77 AJIL 413; Anthony D’Amato, “Trashing Customary International Law" (1987) 81 AJIL 101; Frederick Kirgis Jr, "Custom on a Sliding Scale” (1987) 81 AJIL 146; John Tasioulas, "In Defence of Relative Normativity: Communitarian Values and the Nicaragua Case" (1996) 16 Oxford J Legal Stud 85; Anthea Elizabeth Roberts, "Traditional and Modern Approaches to Customary International Law: A Reconciliation” (2001) 95 AJIL 757.
} 
small community of a few hundred members, compared to the millions that domestic law regulates. And it is horizontal law, rather than vertical law, that depends largely on treaties between states or the emergence of customs among states for the generation of new norms. Therefore, regulating a sovereign state in international law is more like regulating a lawmaker in municipal law than like regulating a private individual. ${ }^{10}$

This quasi-legislative function of much state compliance raises important issues for the kind of moral authority international law has over state decision-making. I will preface two points here. First, the virtues of good governance will be pertinent to determining the content of most states' obligations under much international law. The way in which international law is morally binding for states (and other agencies) will be partly determined by what international law ought to be. Second, in many circumstances, more powerful or influential international agents will have more forceful obligations to abide by international law than less powerful or influential agents.

In light of the fact that customary practice partly determines content for much international law, norms can occupy an intermediary status between legal non-existence and well-established validity. We can speak of norms as crystallizing, as developing, as having some basis in state practice, all the while recognizing that they are not indubitably established as law. I do not want to make these norms ontologically weird, and the view I espouse here is consistent with contemporary forms of legal positivism, so we could also characterize such norms as live candidates for full recognition in international law." The social reality is that some significant quantity of state behavior and decision making proceeds as if the norm is law, but not with sufficient generality, regularity, or recognition by others that the behavior is a matter of compliance with international law to incontrovertibly establish the norm as law. I will call such intermediate norms "nascent law." Nascent law may eventually come to be widely recognized as law, occupy the intermediate status indefinitely, or whither and no longer serve as a source of guidance for international agents.

As indicated earlier, nascency is often thought to imply that a norm is, in some important sense, non-binding. The assumption is implicit in a mode of reasoning that frequents academic, political, and legal forums. Norm $\mathrm{N}$ is suggested to bind a state as a matter of international law. In response, effort is taken to show that $\mathrm{N}$ is not, in fact, wholly supported by the relevant legal

\footnotetext{
${ }^{10}$ Jeremy Waldron, "The Rule of International Law” (2006) 30 Harvard JL \& Pub Pol'y 15 at 23.

${ }^{11}$ I consider in greater detail below at the text for footnote 36 how we should think about these norms from the standpoint of legality. For a discussion of how we can accommodate developing customary international law on positivist assumptions, see Lefkowitz, "(Dis)Solving the Chronological Paradox in Customary International Law: A Hartian Approach," supra note 1.
} 
sources. For instance, while it may be acknowledged that some state practice is consistent with N, and $\mathrm{N}$ has some support in the opinio juris of states or international institutions, it is argued that $\mathrm{N}$ has insufficient support on either axis to be regarded as genuine law. The practically important conclusion is that the state is (in some sense) free from N. Slightly differently, the whole point of making the argument is to show that the practical orientation that a state can permissibly have towards $\mathrm{N}$ is different than it would be if $\mathrm{N}$ were well-established. The legal nascency of a norm is noticed in legal argument because it is seen as sufficient for blocking an attribution of a practically significant obligation to comply with the norm in virtue of its status in international law. The fundamental thought behind this mode of reasoning is mistaken.

It is worth emphasizing that the issue raised here is a moral one concerning the character of state responsibility under international law. My use of "practical reason" is meant to focus attention on this matter. ${ }^{12}$ It is implausible that the interest of the ILC in legal nascency is driven solely by a conceptual concern with whether nascent law is bona fide law. The thought must be (at least partially) that that issue bears on proper conduct such that the nascent legality of a norm automatically affects the role the norm plays in well-conducted practical reason.

\section{The Bindingness of Nascent International Law on Practical Reason}

I will first give the argument in its general form, and then illustrate its significance in terms of some examples in the next section. Take some nascent international legal norm, $\mathrm{N}$, that has the following characteristics: (1) Acting in accordance with $\mathrm{N}$ is, for subject states, sometimes imprudent in the sense that doing otherwise than it demands would occasionally be more optimal from the standpoint of those states' short- and long-term interests. (2) $\mathrm{N}$ does not merely replicate the demands of some moral requirement fully expressible without the existence of a legal or social order. For example, it does not simply demand that one not violate a moral human right to bodily integrity without adequate moral justification -- such a right is effable and morally binding without the assistance of a legal order. ${ }^{13}$ (3) $\mathrm{N}$ is morally suboptimal in the sense that it would be better, all

\footnotetext{
${ }^{12}$ I intend "practical reason" here to be ecumenical regarding conceptions of practical reason. I pursue clarification of the proper role of legal nascency in practical reasoning without committing myself to some special view about the precise nature of practical reason. We can ask whether a norm's legal nascency justifies an attitude regarding its mandatoriness without, e.g., saying whether mandatoriness is a matter of exclusionary reasons. See Joseph Raz, Practical Reason and Norms (Oxford: Oxford University Press, 1975). Deploying the idea of practical reason here assists the right kind of theoretical focus.

${ }^{13}$ I am not claiming that such moral norms cannot be legal norms also. I am not entering that debate here. I am merely stipulating that $\mathrm{N}$ is not simply this kind of norm.
} 
things considered, to have some other norm similar to $\mathrm{N}$ (e.g., $\mathrm{N}_{2}$ ) or some other norm very different from $\mathrm{N}$ (e.g., M) operative in international law.

Now, imagine that $\mathrm{N}$ is (counterfactually) well-established law and consider why a state would, in these circumstances, be bound by it. As discussed above, it is unlikely to be in light of a general, generic, prima facie political obligation to obey international law. At least, assume for the moment that general political obligations are non-operative. Moreover, its mere status as positive law does not, by itself, imply that states have a significant moral reason to obey it. Legal validity does not imply a moral obligation to obey. ${ }^{14}$ If $\mathrm{N}$ is binding, then, it must be in virtue of the fact that being governed by $\mathrm{N}$ achieves, in the context, some morally important end. If a state has moral reason to comply with fully valid $\mathrm{N}$, because $\mathrm{N}$ is law, this must be in light of compliance's contribution to some morally significant outcome. ${ }^{15}$ Slightly differently, if the fact of N's legal validity should be seen by the practical reason of subjects as a moral reason to act as $\mathrm{N}$ requires, this is a function of legality's relationship to a morally worthwhile aim.

Moreover, if $\mathrm{N}$ is binding in the sense of being obligatory for a state to observe, this is a result of the mandatory character of the end for the subject. To say there is an obligation is to say that there is a moral reason for acting that, unless overridden by some other moral demand, ought settle the agent's course of action. Obligations are not supererogatory, and cannot be overridden by mere inclination or prudence when the personal interest at stake is not of comparable moral significance. ${ }^{16}$ Hence, if fully valid $\mathrm{N}$ is binding, in that its demands deserve regard as obligatory in practical reason, this is in light of N's relationship to an outcome the agent has a duty to (help) secure.

What kinds of ends could give international law this sort of normative force? Again, $\mathrm{N}$ is not merely articulating an independently existing moral demand and is, in fact, ethically suboptimal

\footnotetext{
${ }^{14}$ A point well at home in legal positivism. See, for example, Hart supra note 1, at 185-212; David Lyons, "Moral Aspects of Legal Theory" in Moral Aspects of Legal Theory: Essays on Law, Justice, and Political Responsibility (Cambridge: Cambridge University Press, 1993) at 64-101. However, it is a point that is conceded by many philosophers who would call themselves natural law theorists. See, for example, Mark C Murphy, Natural Law in Jurisprudence and Politics (Cambridge: Cambridge University Press, 2006) at 1-60. Dworkin may be an exception, but that is because legal validity is established by providing some moral political justification for the well-accepted elements of legal practice. See generally Ronald Dworkin, Law's Empire (Cambridge: Harvard University Press, 1986).

${ }^{15}$ This way of putting the point is consistent with a Razian analysis, but again, does not require it.

${ }^{16}$ The question of when personal interests are actually of such moral significance is not a matter of anyone's discretion, but an issue requiring discernment.
} 
compared to other possible positive norms. This question takes us into debates about the moral functions of international law, about what international legal governance is properly concerned with accomplishing. Prominent suggestions include: peace, cooperation and coordination among states, protection of human rights, justice, and international democracy. ${ }^{17}$ I will remain somewhat agnostic about the central moral functions of international law, and which are of obligatory concern to states, since it does not affect the argument here regarding nascent law's capacity to bind. However, for purposes of illustration, I will emphasize one end plausibly and widely regarded as of mandatory concern to states: the protection of human rights. There is a large and growing literature on human rights that disputes their precise character, content, basis, and addressees. ${ }^{18}$ What is less disputed (among those who use the idea) is that human rights are non-transactional, somewhat political context insensitive, and difficult to alienate moral claim-rights possessed by individuals in virtue of some aspect of the status of being human, and that they are of basic significance to international morality. I will briefly focus on Allen Buchanan's approach below because it articulates some core ideas common among much of the theory, situates the discussion explicitly in terms of international law, and (as things stand) is plausible. However, if international governance is properly concerned with something else, or we ought to understand human rights somewhat differently, then we can plug that into this part of the argument. ${ }^{19}$ What is important for our purposes is that international

\footnotetext{
${ }^{17}$ Legitimate functions will likely vary, to some degree, from department to department such that, for example, there are values of special concern to international criminal law. See, e.g., May supra note 2. ${ }^{18}$ See Rawls, Griffin, Beitz, Buchanan supra note 2. Other prominent contributions, representing the theoretical pluralism, include Henry Shue, Basic Rights (Princeton: Princeton University Press, 1980); Martha C Nussbaum, Women and Human Development: The Capabilities Approach (New York: Cambridge University Press, 2001); James Nickel, Making Sense of Human Rights, 2nd ed (Malden: Blackwell, 2007); Joseph Raz, "Human Rights Without Foundations" in Samantha Besson \& John Tasioulas, eds, The Philosophy of International Law (New York: Oxford University Press, 2010) at 32137; Rainer Forst, "The Justification of Human Rights and the Basic Right to Justification: A Reflexive Approach" (2010) 120 Ethics 711; Carl Wellman, The Moral Dimensions of Human Rights (New York: Oxford University Press, 2011).

${ }^{19}$ It might be doubted that I can leave matters so formal at this point, i.e., that I can avoid specifying more conclusively what counts as a morally mandatory end for subjects of international law. I present the argument as adaptable to variety of understandings of international morality, but the replacement/addition I am suggesting here might be thought unacceptable. The plausibility that international law should promote human rights, for instance, depends upon which conception of human rights is affirmed. I will consider this worry more fully below at the text for footnote 43 , but as an initial reply, I do think relying upon interchangeability is appropriate here. A division of labor in normative theorizing is frequently acceptable and helpful in making progress in specialized topics. Sometimes we are interested in the
} 
law is binding when: (1) it facilitates the realization of some morally important end because it is law, (2) it facilitates this end (in part) because it is producing an international order, (3) states have a duty to contribute to the realization of that end, and (4) compliance on a particular occasion contributes to the achievement of that end.

Buchanan conceives of human rights as the core, but subpart, of the demands of justice. Human rights concern the protection of vital, universal human interests that deserve protection by human institutions. If I have a human right to free assembly, for example, that implies that I have important interests that depend on such freedom, and that social institutions ought to ensure that I can assemble freely. On this view, human rights express an equal regard for persons-foundational to justice - but they are not as demanding as complete justice. Nonetheless, human rights can be used as a benchmark for legitimacy, understood as the permissible exercise of political power, and for grounding our commitment to political institutions, including international law. It is now familiar in political theory to suggest that we have a natural duty to support or promote the development of just institutions. Much of our commitment to international law, Buchanan contends, ought to be based in recognition of our natural duty to justice (rather than, e.g., consent)..$^{20}$ He summarizes: "We are only obligated to work with others, utilizing our shared institutional resources and augmenting them when necessary, to help ensure that all persons have access to institutions that protect their basic rights, so long as we can do so without excessive costs to ourselves."

To be properly convinced, we would need the full argument. Again, though, we need simply notice that the protection of human rights is plausibly the kind of morally mandatory end that could make international legal norms obligatory for states. There could be others. In any case, the fact that makes fully valid $\mathrm{N}$ binding, what will make it non-optional for practical reason to consider its (morally suboptimal) demands as a basis for a course of action, is that letting international law govern in the circumstances will assist with the realization of some mandatory end

substance of the legitimate aims of a social order, and other times in the character of legal authority. The analysis here focuses on the latter, and (attractively, I think) can adapt to various theoretical outcomes on the former. The benefit of dividing theoretical labor (given that we cannot say everything at once) is the potential advancement of our understanding of nascent legal authority in particular, and the precise way in which it relates to the substantive aims of the legal order.

${ }^{20}$ See generally Allen Buchanan, Justice, Legitimacy, and Self-Determination: Moral Foundations for International Law (New York: Oxford University Press, 2004).

${ }^{21}$ Ibid at 468 . 
(e.g., the protection of human rights). Moreover, if international law is facilitating some end via governance, i.e., by mandating some course of action, this facilitation will normally be a function of the establishment of an international order (e.g., by coordinating action). Consequently, one relevant concern will be whether to sustain or promote an international order that abides by $\mathrm{N}$. Letting $\mathrm{N}$ govern in the circumstances may affect how far other states will comply with $\mathrm{N}$ (and this will vary based on a subject's prominence in that order). Given our stipulations regarding N above, it would be morally preferable to have $\mathrm{N}_{2}$ or $\mathrm{M}$ as norms of international law - they would better perform the relevant functions. However, if $\mathrm{N}$ is well established (as a matter of social fact), $\mathrm{N}_{2}$ and M may be unavailable. In that circumstance, the moral ends of international law are best achieved by compliance, and the content of $\mathrm{N}$ appropriately sets the agenda for practical reason. For instance, although it is probably morally suboptimal to have humanitarian intervention governed by the UN Security Council (compared to all other feasible procedures), states are very likely bound by its determinations on such matters because: (1) of the importance to human rights of having intervention constrained by some multi-lateral process, and (2) compliance on particular occasions affects how far the international order is factually governed by such a process at all.

Moving forward in the line of reasoning, if the ends international law (or some part of it) facilitates are of mandatory concern, they are such irrespective of the state of international law. For example, states have a duty to protect human rights independent of international institutions that may assist with such protection. It is a natural duty. The global institutional order will simply affect the type of action required for a state to discharge that duty. Thus, states should be concerned to pursue the mandatory ends that the governance of fully valid $\mathrm{N}$ assists with irrespective of whether $\mathrm{N}$ is valid.

Return to the actual case where $\mathrm{N}$ is nascent. If $\mathrm{N}$ is nascent, the same mandatory ends will be salient as would be if $\mathrm{N}$ were fully valid. Hold all facts stable between the real case and the counterfactual except the legal status of $\mathrm{N}$. N requires the very same action (it has the same normative content), and a state can be (depending on international circumstances) in a position to support or undermine its institutionalization. A nascent norm has some institutional support; it is a live candidate for full legal recognition. Letting $\mathbf{N}$ govern in the circumstances, and acknowledging that $\mathrm{N}$ is governing in the circumstances, may be instrumental to a global order that is governed by N. $\mathrm{N}_{2}$ or $\mathrm{M}$ may be ethically superior as norms for international law, but they may not have the requisite institutional support to be viable candidates, i.e., compliance with them would not 
contribute to the development of a global order governed by them. If obedience to $\mathrm{N}$ promotes the relevant mandatory ends as well as possible in the circumstances, then $\mathrm{N}$ is binding - its requirements are obligations for practical reason. $\mathrm{N}$ ought set the agenda for practical reason in virtue of its status in the international legal order.

I will address some complications in a moment, but the upshot is that the legal nascency of ethically suboptimal $\mathrm{N}$ does not imply that it is non-binding on the responsible practical reason of states. A nascent international legal norm may be just as obligatory, and for the very same fundamental reasons, as a norm that is recognized as fully valid in international law. Showing that a norm has only limited support in international law is insufficient for demonstrating that a state would not be irresponsible, with regards to its duties under international law, in not permitting it to govern.

A reformulation and summary of the argument is as follows:

1. International legal norms are binding in virtue of their legality when compliance facilitates, in part by producing an international order, the achievement of some morally mandatory end. The law-making properties of international legal norms are a reason for compliance in virtue of their ordering of state behavior and deliberation.

2. A morally mandatory end is one that is non-optional for agents to pursue when there are facilities for pursuing it.

3. Nascent law can be, precisely because of its intermediary legal status, a facility for achieving morally mandatory ends via the production of an international order. In other words, compliance with nascent law (especially when it is announced as such) can facilitate an international order that accomplishes what it must, and this facilitation is a function of the properties that make international norms legal.

4. C1: Nascent law can be binding, in virtue of its status as law, on practical reason. Practical reason must take the course of action directed as obligatory because of norm's status as nascent law. It can be binding, from the standpoint of practical reason, in the same sense as other international law (i.e., the law-making properties of international law are a reason for compliance). ${ }^{22}$

5. C2: Demonstrating a purported international legal norm's nascency is insufficient for showing it to be non-binding on its purported subjects.

\footnotetext{
${ }^{22}$ I will say more about nascent law's status as law, and why it is correct to treat the law-making properties as reasons in cases where it binds, below at the text for footnote 37 .
} 


\section{Two Complications}

Two complications should be addressed before moving on to examples. The first concerns collective action. We should wonder whether the existence of a nascent norm potentially related to a mandatory end obligates a state to comply regardless of the behavior of other states. The answer, on this account, is no - how far other states can be expected to comply (given one's own compliance) affects whether one is bound insofar as collective action is relevant to achieving the salient end. Hence, influential states have more demanding obligations under international law (their compliance is more likely to bring about the requisite collective action). This answer, however, might be thought to point to an important difference between established and nascent doctrine. Compliance with settled norms will normally be more likely to promote mandatory ends accomplished by collective compliance given their status as settled law. Compliance with a nascent norm (even by an influential actor) may not "catch on," or not as widely, whereas compliance with established doctrine may further entrench near-universal recognition of a norm facilitative of an end. I admit this point, but it does not threaten the central argument - it only illustrates how complicated matters are for responsible subjects of international law. First, there will be cases where public compliance will likely contribute to or achieve desirable ordering. Nascency would not, in this case, categorically change the obligation. Additionally, the role the nascent legal norm appropriately plays in the practical reason of the subject remains qualitatively the same. The norm is binding to the extent, but only insofar as, it is facilitative of a mandatory end. This is likely true of international law generally. A legal norm sets the agenda; it articulates the course of action to be contemplated by practical reason. The agenda set by the legal norm is capable of accomplishing morally mandatory ends via global ordering because it is law, i.e., because it is recognized (by various actors) as normative. The international legal norm is binding insofar as compliance is related to these ends (either directly, or by sustaining the normative attitudes). The same obtains for nascent norms of international law: a nascent norm of international law is a candidate (and, to some extent, operative) agenda-setter in light of its legal status, and it is binding because (and insofar as) compliance is related to morally mandatory ends of global governance.

The second issue concerns the wider array of norms that are frequently available with regards to an issue when it comes to nascent doctrine. A state may have some ability to shape the content of the norm that is to become established as law by the character of its compliance (in ways 
that hold less frequently for better established law). The nascent norm may be somewhat indeterminate, or subject to some modification in light of its nascency, such that the way in which a state complies will affect the content of the norm's requirements. This interpretive leeway is not license for a state to manipulate the international order for its own interests; it is a demand that a state perform its governance role in the international order in a way that, from an impartial moral political point of view, best achieves the moral aims of that order. If two nascent norms are equally available, and mandatory ends of the global order are at stake on a particular occasion, then a state is bound by the ethically superior nascent legal norm. ${ }^{23}$

\section{Cases}

I will now illustrate the significance of the above argument for state decision-making by considering two cases of nascent legality. Perhaps the cases below will also provide some intuitive support for my position, but that is not their primary purpose. Rather, I hope to show that my contention that nascent legal norms can be binding in virtue of their legal status is quite significant for the character of the responsible practical reason of states under international law.

\section{A. Armed Attack and Collective Self Defense in Nicaragua}

In the 1984 case Nicaragua v. U.S., the International Court of Justice (ICJ) ruled that the United States had violated customary international law in its support of the Contras (the armed rebellion challenging the Sandinista government) and by its mining of Nicaraguan harbors. ${ }^{24}$ The case has received a great deal of attention for a variety of reasons, but my interest here is narrow. I am not addressing the issue of whether the ICJ had jurisdiction, decided the case correctly, or reasoned appropriately. My interest here is in the responsibilities of states under nascent international law and, in particular, the responsibilities of the United States with regards to a particular piece of (then) nascent international legal doctrine. ${ }^{25}$ Although it eventually opted out of the proceedings, the U.S. initially defended its intervention in Nicaragua on the basis of collective self-defense. The U.S. claimed that it was acting on behalf of El Salvador, who had requested assistance in repelling Nicaraguan aggression. To summarize, the assertion was that Nicaragua was providing arms and

\footnotetext{
${ }^{23}$ The relevant sense of ethically superior here will be settled by the mandatory ends at stake, e.g., which norm better protects human rights, or what ends are ethically more pressing as a matter of substantive political morality.

${ }^{24}$ Case Concerning Military and Paramilitary Activities In and Against Nicaragua, [1986] ICJ Rep 14 [Nicaragua $v$ US].

${ }^{25}$ The issue of responsible adjudication in international courts and responsible state reasoning under international law are, I think, closely related. However, I will not argue for that here.
} 
other support to rebel groups in El Salvador and, as a consequence, the U.S. could permissibly assist (via proportional intervention in Nicaragua) El Salvador in protecting its sovereignty and territorial integrity. ${ }^{26}$

The ICJ acknowledged that customary international law recognizes collective self-defense as an exception to the general prohibition on the use of force (irrespective of any agreements amongst the states). ${ }^{27}$ So, let us take that as settled law. The question for the court, then, was whether this exception applied in the circumstances, whether this was a matter of self-defense. The ICJ understood this as an issue of whether Nicaragua had engaged in an "armed attack" against El Salvador. It stated: "In view of the circumstances in which the dispute has arisen, reliance is placed by the Parties only on the right of self-defence in the case of an armed attack which has already occurred, and the issue of the lawfulness of a response to the imminent threat of armed attack has not been raised." ${ }^{28}$ In other words, no one contended that Nicaragua was posing an imminent threat of armed attack. The question was only whether its prior (and alleged) material support of armed groups within El Salvador constituted an armed attack that would render permissible armed intervention on the part of the U.S.

So, what constitutes an "armed attack"? Here the ICJ appealed to UN General Assembly Resolution 3314 (XXIX) defining aggression, with the notion that the resolution is evidence of an opinio juris on the part of states with regards to its provisions (and, therefore, has standing as customary international law). The resolution provides a list of actions that qualify as aggression, including invasion, military occupation, bombardment, blockade, attack on armed forces, and the "sending by or on behalf of a State of armed bands, groups, irregulars or mercenaries, which carry out acts of armed force against another State of such gravity as to amount to the acts listed above." ${ }^{29}$ The resolution indicates that the list is not meant to be exhaustive, but leaves further determination up to the Security Council. ${ }^{30}$ The most relevant of the listed acts seems to be the last quoted. Does material support for an independent armed resistance within another state's territory amount to sending an armed force against that state? The ICJ gave a negative answer to this question:

\footnotetext{
${ }^{26}$ For a discussion of some of the doctrinal issues regarding collective self-defense in the case, see Zia Modabber, "Collective Self-Defense: Nicaragua v. United States" (1988) 10 Loy LA Int'l \& Comp L Rev 449 .

${ }^{27}$ Nicaragua $v$ US, supra note 24 at para 193.

${ }^{28}$ Ibid at para 194.

${ }^{29}$ GA Res 3314, UNGAOR, 29th Sess, Supp No 31 142, UN Doc A/9631 (1974), art 3.

${ }^{30}$ Ibid at art 4.
} 
The Court sees no reason to deny that, in customary law, the prohibition of armed attacks may apply to the sending by a State, if such an operation, because of its scale and effects, would have been classified as an armed attack rather than as a mere frontier incident had it been carried out by regular armed forces. But the Court does not believe that the concept of "armed attack" includes not only acts by armed bands where such acts occur on a significant scale but also assistance to rebels in the form of the provision of weapons or logistical or other support. ${ }^{31}$

The tortured syntax of the ICJ's judgment expresses the view that material support for rebels is not of sufficient scale to constitute an "armed attack." Thus, the U.S. intervention in Nicaragua, including the mining of its harbors, cannot be justified by appeal to collective self-defense, since Nicaragua never engaged in an armed attack against El Salvador (even granting the U.S.'s factual contentions). The exception to the general prohibition on the use of force does not apply, in this case, to the U.S. ${ }^{32}$

Again, the question here is not one of whether the ICJ decided Nicaragua v U.S. correctly. What is of special interest for us is the significance of the General Assembly resolution to which the court appealed for responsible U.S. decision-making. Was the U.S. bound by Resolution 3314 and its definition of aggression in terms of "armed attack"? We can well imagine the U.S. responding to an affirmative position on the question, suggested by the court's reasoning, as follows:

We are not bound by Resolution 3314. First, it is merely a General Assembly resolution, and such resolutions, according to the UN Charter, have only advisory status for the Security Council. In fact, this was the General Assembly's understanding of the status of the resolution. The Security Council has never taken the view of the General Assembly on this matter. Second, regarding the definition's status as customary law, this has hardly been established conclusively. General, widespread state compliance with the definition of armed attack has not been demonstrated. Third, our own view is that "armed attack" and aggression ought to be understood more broadly than the resolution suggests. We acted within the sphere of our responsible discretion under international law.

Do such considerations show that the resolution's definition of "armed attack" is non-binding on the U.S.? Do the considerations adduced above assist the U.S. in showing it acted within its responsible discretion under international law? No, and (for the most part) no. Consider the issue in light of these earlier theoretical points: (1) international law's capacity to bind is normally a

\footnotetext{
${ }^{31}$ Nicaragua $v$ US, supra note 24 at para 195.

${ }^{32}$ Ibid at para 201.
} 
function of legality's relationship to mandatory ends, (2) this relationship is normally constituted by the ordering of state behavior, (3) nascent legality can, in various circumstances, have this relationship, and thus (4) nascent legal norms can bind states in terms of their responsibilities under law. The resolution arguably made available a norm of international governance concerning the definition of aggression. The norm may be morally suboptimal in a number of respects, i.e., it may be the case that it would be better if some other definition of armed attack were operative in international law. Yet, insofar as some more optimal definition is not proximately available, then that is beside the point. It is quite plausible that having settled conventions concerning the definition of aggression contributes to morally mandatory ends, both in terms of constraining aggressive and interventionist behavior, and in constraining responses to such behavior. Peace, security, global stability, and human rights are plausibly implicated. Moreover, given the prominence of the U.S. in global affairs, compliance (with public acknowledgement thereof) would plausibly contribute to a global order governed by the resolution's definition. Thus, the U.S. may have been bound (depending upon the social circumstances) by the UN General Assembly resolution's definition of armed attack. It had reason to treat the norm as determining the appropriate course of action because of its intermediary legal status. It was binding in the same way it would have been had it been better established in customary international law. When we concern ourselves with the question of the U.S.'s responsibilities under international law, the above rebuttal is unsuccessful.

\section{B. Domestic Amnesties for International Crime}

Another issue of recent concern has been the legality of states offering amnesty to persons residing in the state's borders for international crimes committed within the territory, i.e., the issue of domestic amnesties. After a careful consideration of the relevant treaty law, customary law, and international court rulings, Mark Freeman and Max Pensky conclude: "In the current geo-political constellation, international criminal law is not able to offer clear guidance regarding the legality of domestic amnesties for international crimes. ${ }^{{ }^{33}}$ I will not rehearse the entirety of their reasoning here, but Freeman and Pensky contend that a prohibition on such amnesties cannot be unambiguously derived from treaty language. They also suggest that, although there is arguably

\footnotetext{
${ }^{33}$ Mark Freeman \& Maxim Pensky, "The Amnesty Controversy in International Law" in Leigh A Payne \& Francesca Lessa, eds, Amnesty in the Age of Human Rights Accountability: Comparative and International Perspectives (New York: Cambridge University Press, 2012) 42 at 64.
} 
some support for such a prohibition in the opinio juris of states, the regular contradictory practice of states disables the contention that it is established customary law. In fact, it appears that domestic amnesties have become increasingly common tools for addressing real world problems of transitional justice. ${ }^{34}$ From the standpoint of international law, then, a prohibition on domestic amnesties is unsettled and nascent.

Importantly, domestic amnesties can assist in facilitating peaceful resolutions to violent intra-state conflicts. Yet, the crimes that are in question are serious ones (e.g., crimes against humanity and genocide), and there may be pressing issues of justice and discouraging future similar behavior. For a state attempting to discern its responsibilities under international law, then, how should it regard the nascent prohibition on domestic amnesties? From the analysis earlier, we can say the following. First, the moral situation of the state is different than it would be if there were no available international norms governing domestic amnesties. In that case, the state could simply weigh directly the moral merits of proceeding with an amnesty, including the goods of future domestic political stability and peace. In actual circumstances, however, the state is in a position of governance, such that its behavior will help determine how the global order is to regard amnesties. Thus, part of the question for the state is whether the international order ought be governed by a norm prohibiting domestic amnesties, or by some version of such a norm. Second, states will differ in the degree to which they are in governance positions, and this will affect the extent to which those states have a responsibility to promote and sustain a global order that facilitates mandatory moral ends. Insofar as there are compelling moral merits to a global order governed by an antiamnesty norm, and the state is in a position of shaping that global order, the state is bound by the norm. The state is bound by the norm in virtue of its status in international law because, absent its nascent status, the state would not be so bound. Third, even if the norm is binding, this is not the end of the story for responsible deliberators. The norm will have to compete, in the practical reasoning of the relevant agents, against other (perhaps quite compelling) moral demands. Its proper force in practical reason will depend upon how far the ends of a morally desirable global order are at stake. This would be exactly the situation of states if a prohibition against amnesty

\footnotetext{
${ }^{34}$ Ibid at $42-65$.
} 
were well-established international law. ${ }^{35}$ Finally, in the actual circumstances, the character of a state's compliance with the anti-impunity norm may affect the character and content of that norm. This should inform the state's decision-making.

\section{Objections and Replies}

I have attempted to preempt some worries regarding my above conclusions. These include concerns that legal nascency affects the ability of a norm to serve the ends of global governance, that my approach entitles states to undesirable license and discretion under international law, and that my conclusions are practically insignificant from the standpoint of the responsible practical reason of states. I will here consider several additional objections, the first of which will seek to clarify nascent law's status as law.

\section{A. The Legal Status of Nascent International Law}

My argument concludes that nascent international law can be binding on practical reason in virtue of its status as law. One might worry about the propriety of describing such norms as law at all. The reasoning could be as follows: To call a norm "nascent law", as opposed to "law", could only be meant to indicate that the norm has not fully satisfied the criteria of legality. This is not an epistemic issue concerning whether we have sufficient evidence for warranted certainty that a norm is law. If that were the issue, then it would be appropriate to describe the problem in terms of ignorance rather than nascency. "Nascency" concerns the character of the object in question. Even if we were fully informed about state practice and the criteria of legality, we might regard a norm as nascent if it does not fully meet the criteria of legality. To continue, if a norm has not satisfied the criteria of legality, then it is not law. If a norm is not law, it cannot be binding in virtue of being law. In sum, nascent international law cannot be binding in virtue of its legality, since it is not law.

In response, I grant that nascent law cannot be binding in virtue of being incontrovertibly determinate positive law. However, nascent law does have an intermediary legal status that is a function of the criteria of legality, i.e., its nascence is a function of being partly recognized by the existing criteria of legality. It satisfies those criteria to a degree, but the criteria are vague, such that

\footnotetext{
${ }^{35}$ With the minor difference that sanctions from the international community might be attached to noncompliance. Set this prudential consideration aside since we are considering here how the fact of an international legal norm can render non-compliance irresponsible.
} 
we cannot incontrovertibly conclude that the norm is law. Vagueness, as I use the term, is a specific kind of indeterminacy. Jeremy Waldron summarizes:

A predicate $P$ is vague if there are objects or instances $\mathrm{x}_{1}$, $\mathrm{x}_{2}$, etc. within the domain of the normal application of terms of this kind such that users are characteristically undecided about the truth or falsity of " $\mathrm{x}_{1}$ is $P$," " $\mathrm{x}_{2}$ is $P$," and they understand that indecision to be a fact about the meaning of $P$ rather than about the extent of their knowledge of $\mathrm{x}_{1}, \mathrm{x}_{2}$, etc...."Blue"-colored is vague because, although the predicate is supposed to apply to and discriminate among color patches, most of us would hesitate about saying of certain shades of turquoise and lavender either that they were blue or that they were not blue. ${ }^{36}$

When the criteria of legality are indeterminate in this sense, there may be norms that satisfy the criteria to some degree, and thus are arguably law, but not to the degree that we feel wholly justified in calling them law. ${ }^{37}$ Nascent norms of international law are such norms. ${ }^{38}$ To emphasize, they are such norms precisely in virtue of being recognized (to a degree) by the criteria of legality - it is in light of law-making properties that they are nascent international law. They have a status as law, in this sense. Nascent international law can be binding in virtue of this status because complying with the norm may promote (because of its somewhat recognized status in international law) a global order governed by that norm, and a global order governed by that norm serves an end of mandatory concern to the agent. There may be ethically superior governance norms, but their lack of legal recognition may render them unavailable.

To illustrate, consider this from the standpoint of Hartian legal positivism. As discussed earlier, customary international law is understood to require both regular and widespread practice and an opinio juris on the part of states. ${ }^{39}$ We could plausibly regard these requirements, from a Hartian standpoint, as part of the rule of recognition for international law (i.e., they specify the criteria of legality for a certain type of law, namely, customary international law). Both

\footnotetext{
${ }^{36}$ Jeremy Waldron, "Vagueness in Law and Language: Some Philosophical Issues" (1994) 82 Cal L Rev 509 at 513.

${ }^{37}$ The degree to and way in which the criteria of legality are vague will vary from legal system to legal system (insofar as systems have qualitatively different criteria).

${ }^{38}$ Vagueness does not always imply nascency. Turquoise is not nascently blue. "Nascency" seems applicable in cases where a vague predicate is questionably (because of its vagueness) predicable of an object that is in the early part of a process that will, under felicitous conditions, lead to the predicate being unquestionably predicable of the object.

${ }^{39}$ I offer an illustration in terms of customary international law, but the same point would hold for other domains of international law that contain nascent doctrine.
} 
requirements are vague. They are not meaningless requirements, for they clearly exclude and include rules, and jointly exclude and include rules as customary international law. However, there will be borderline cases for what counts as regular and widespread practice, and for what counts as an expression of an opinio juris. ${ }^{40}$ For the infinite array of possible legal rules, there are three relevant possibilities for customary international law. First, the rule clearly fails with regard to either criterion, and is not law. Second, the rule clearly succeeds with regard to both criteria, and is law. Third, the rule does not succeed with regard to both criteria, but also does not clearly fail either of them (though, it may clearly succeed on one, and be arguable but unclear on another). The third possibility describes the class of nascent customary international legal rules. These rules are nascent in virtue of the criteria of legality supplied by the rule of recognition, and they can be binding (when the above adduced conditions are met) in virtue of those criteria. They have some recognition in existing legal institutions. Slightly differently, the lawmaking social facts (i.e., the social practice that is, on Hart's theory, the rule of recognition) can make certain rules reasons by selecting them out from the array of possible rules. This is true for both settled and nascent international law, and under the same moral conditions.

\section{B. Customary International Law as a Mode of Governance}

Another concern might be that my account of how international law binds practical reason, with its focus on developing customary law, counts as an endorsement of customary law in international relations. It is far from clear, however, that customary law is ideal as a mode of international governance. We might have concerns, much in the vein of Jeremy Bentham's apprehensions regarding the common law, ${ }^{41}$ about the extent to which we have commonly recognized traditions and practices in international relations, and this leaves customary law worryingly non-public. Law can only perform its fundamental function of providing a secure social order well if it is manifest (at least to experts) and public. Similarly, we might regard customary international law as objectionably undemocratic, especially given the asymmetrical ability of states to shape it. Treaty law, given its

\footnotetext{
${ }^{40}$ In addition, there will be vagueness regarding the extent of opinio juris required. Moreover, the rule of recognition may stipulate more complex and extensive criteria for customary law, but that does not affect the theoretical point here: vagueness in the criteria of legality ground the possibility of nascent law such that it is sensible to speak of nascent law as binding in virtue of its legal status.

${ }^{41}$ For an excellent discussion of Bentham's critique of the common law, see Gerald Postema, Bentham and the Common Law Tradition (Oxford: Clarendon Press, 1986).
} 
(sometimes) consensual character, and multi-lateral legislative procedures, given their greater approximation of democratic process, are preferable.

In response, I am not advocating customary international law as an ideal model for international governance, nor am I denying the desirability of other international legislative institutions. It appears quite clear that the current state of international law is far from ideal from the standpoint of human rights, justice, or democracy. The literature on its failings is extensive. However, customary law is, for the foreseeable future, a significant part of the international legal order. Insofar as state compliance with such law is related to the mandatory ends of global governance, I have argued, states are bound by it. The horizontal character of the current international legal order implicates states in a responsibility for sustaining that order and, when possible, shaping it to better serve its moral ends. It is the latter responsibility that makes nascent law so interesting - it puts states in a position to help create global order more respectful of human rights (or whatever other ends are of mandatory concern to states).

Nonetheless, it might be thought that I have significantly de-democratized international legal authority, since the actual content of (morally) authoritative international legal norms will depend upon the interpretation of prominent, influential states. It is hard to dispel this worry altogether, but I should reiterate a couple of points, and bring into relief two others that have been sitting in the background. First, influential states do not have license, on my approach, to manipulate international law to simply further their own perceived interests. Second, the upshot of my argument is that the powerful and influential are more strongly bound by international law, since their behavior will have a greater affect on the character of the legal order. Third, the approach to authority I am advocating here emphasizes the role of multilateral institutional processes, especially those not as dominated by a small number of states as the Security Council, in determining the availability of global governance norms. The UN General Assembly is a far more representative and deliberative institution than the Security Council, and insofar its resolutions serve as a basis for nascent international law (by, e.g., counting as widespread opinion juris), their determinations may be binding on states without the intermediation of the Security Council or an independent treaty. Something similar can be said of multilateral conferences and other international forums. As Samantha Besson notes, the increasing willingness to acknowledge more inclusive forums as 
sources of international law can be seen as a democratization of international legislation. ${ }^{42}$ The approach to the moral authority of international law I defend here shows how consideration of the results of such forums is, in many circumstances, morally mandatory. Finally, the results of treaties and multi-lateral forums will require interpretation, and insofar as such interpretation is horizontal amongst the parties, many of the same issues will arise. Where a treaty norm, e.g., is vague, a state may be bound by a nascent interpretation in light of its being made available by its nascent legal status, and by the norm's service to the relevant mandatory ends.

\section{Morally Mandatory Ends}

Throughout much of my discussion, I have attempted to remain moderately agnostic about which ends are of mandatory concern to states' international decision-making, and which are within the proper purview of international law. My own view is that human rights are the most basic such ends, but arguing for that would require its own paper and substantive consideration of the extensive literature (some referenced earlier) regarding these matters. It is helpful, then, to divide our theoretical labor, with some attention in the literature being specially devoted to the substantive virtues of international governance, and other to the character of international legal authority and how that authority relates to those virtues. Yet, we might wonder whether agnosticism on the moral aims of international law can be sustained for the purposes of the argument here regarding nascent legal authority. Perhaps my case is affected by the content of morally mandatory ends, and thus I cannot satisfactorily leave these ends unspecified. If further specification is required (e.g., in terms of human rights), then more needs to be said about the overriding importance of these compared to other possible candidates. ${ }^{43}$ My response has two parts. First, I defend the substitutability of ends in my argument. Second, should this fail, I consider how damaging it is to my case if I must take a stronger stand on the moral functions of international law.

The very basic schema of the thought is this: morally suboptimal norm $\mathrm{N}$ is binding when its features as a norm make it productive of an end that its subjects have a duty to promote. The form might be adapted to contexts outside of international law in a way that highlights the variables in the structure. Take, for instance, an overly restrictive neighborhood (non-legal) convention regarding noisy activities. We could plausibly say that it is obligatory in light of a personal duty to

\footnotetext{
${ }^{42}$ Besson, supra note 1 at 180-85.

${ }^{43}$ I am grateful to the anonymous reviewer for pressing this issue.
} 
my neighbors' interest in the peaceful enjoyment of their dwellings. Suboptimal convention (C) is binding in virtue of its relationship to end of mandatory concern (E). In considering the compliance obligation, we could perfectly well introduce various other candidates into E (e.g., a duty to not upset important expectations about the social order), or various accounts of $\mathrm{E}$ (e.g., that it is based in justice, solidarity, or some other basic moral virtue). Here, the structure of our various explanations remains the same, in spite of our appeal to different moral ends.

Moreover, we might have a legitimate interest in endorsing the explanatory form itself as one route to substantiating the binding character of $\mathrm{C} .{ }^{44}$ We can say that some morally compelling end best explains how the characteristics of the convention (i.e., the properties that make the convention a convention) are obligation-entailing. We can endorse the form of explaining how $\mathrm{C}$ is binding while rejecting various candidates (e.g., one should comply with $\mathrm{C}$ to protect human rights, to facilitate tranquil living, because I should always defer to my neighbors, etc.), or remaining largely agnostic about which ends (or their basic moral grounds) serve to bind. The form of explanation itself may be of interest to us because it has implications down the line for practical and theoretical issues.

Given the structure of my argument, the same basic strategy is available in the context of international law. In explaining law's capacity to bind, I point to legality's relationship to the mandatory ends of the relevant subjects. We can substitute various candidates without modifying this form - and the form itself turns out to be quite significant. If I have identified a basic way law binds practical reason, the same holds for nascent law (in light of nascent legality).

Perhaps some ends cannot, because of their nature, bear the same relationship to nascent legality that they can to well-established validity. But what kind of end would this be? What kind of end would be such that full possession of the properties that render a norm legal make a norm capable of achieving the end, but partial possession of these properties leave a norm categorically incapable of promoting that end? Peace, stability, coordination, protection of human rights, and cooperation all appear capable (contingently, of course) of being assisted by nascently legal norms. ${ }^{45}$ Strictly speaking, all that the argument needs is for one of these ends to be both of mandatory concern to states and capable of being facilitated by nascent norms. In that case, nascency could

\footnotetext{
${ }^{44}$ In contrast to a form that would employ, for instance, transactions of some sort to establish its binding force.

${ }^{45}$ My examples in text at footnote 24 provide some evidence that nascent legal norms are capable, in principle, of serving important ends of global governance under certain conditions.
} 
not play the role of categorically blocking bindingness in the mode of reasoning illustrated at the start of the paper. It is an upshot of my argument (and one I have emphasized) that states so bound must exercise moral judgment regarding these ends at the point of compliance - and we should be very interested philosophically in the character of these ends. However, this is not an invitation to discretion (it is a demand for discerning moral judgment), and norms can bind in virtue of their legality no less.

If this still is not wholly convincing, and I must supply a basic moral function for international law, then I would say the protection of basic human rights. Here we would want an account that (among other things) indicates the priority of this aim versus others. I cannot supply that in this article, but I can offer a very brief picture illustrating to what the claim amounts. The basic purpose of international institutions is to protect core human interests from standard threats posed by the natural world and social life. International law (even if suboptimal from the standpoint of human rights protection) binds when compliance is instrumental to such protection, and so too does nascent law. Although other aims, e.g., peace and cooperation, may also be important, they are so derivatively or secondarily. In saying this, I would narrow my audience and marginalize from my analysis those who reject human rights, or reject it as a basic aim of international law. Recent work, ${ }^{46}$ however, suggests that this audience is becoming smaller, even if human rights are still in dispute. Again, though, I have attempted to frame the argument in a way that is compelling to a variety of understandings of the basic moral aims of international law.

\section{Conclusion}

It is tempting to think that states' responsibilities under international law are exhausted by settled doctrine in that arena. On this view, states act within the sphere of their responsible discretion, and they are free from positive norms purporting to govern their behavior, when they are in compliance with settled doctrine. UN General Assembly resolutions, emerging norms in international practice, and the like, are non-binding, and states are generally free from well-grounded criticism that they are abrogating their responsibilities under law when they treat them as such (especially when states consider the demands morally suboptimal). I contend here that this tempting, and apparently reasonable, way of thinking about states' responsibilities under law is mistaken.

The central claim advanced by this paper is that nascent international legal norms are capable of binding the practical reason of its subjects in the same way as established international

\footnotetext{
${ }^{46}$ Supra notes 1, 2, 3, 9, and 18.
} 
law. The practical reason of states, whether this reason is being conducted by particular officials, official bodies, or by public deliberation, has to decide on particular courses of action in particular circumstances. International law will frequently forbid or require a course of action for those circumstances. We can say that international law is binding when states are obligated to carry out the terms of international law because of its status as international law. Instead of appealing to political obligation to capture international law's binding character, I have instead focused on morally mandatory ends of global governance (based, I have suggested, in human rights). When letting international law govern in the circumstances is related to the realization of these ends (in a way that would not have been possible absent the law), or to a global order productive of these goods, such law is binding.

Such considerations apply, in the same way, to nascent international doctrine, and it is, therefore, capable of binding. Subjects of international law are bound by it in light of their responsibility to govern the international order well. In a municipal legal system, we may be able to separate sharply the virtues of good governance from those of good citizenship, since we can distinguish easily between legislation and compliance. In the realm of international relations, such a distinction is harder to come by. Subjects of international law will frequently be performing governance functions at the point of compliance. Consequently, a state's regard for nascent law must be responsive to what will best promote those moral aims that properly compel its concern with international law in the first place. 